\section{Discussion}

Our findings show that glycosylation of hair occurs and is increased in diabetes. Furthermore, glycosylation of hair from normal subjects may be increased by incubation with glucose solutions in proportion to the glucose concentration used. The results of reduction with tritiated borohydride and amino acid analysis and of gas-liquid chromatographic sugar analyses indicated that the glycosylation is at least partly accounted for by the presence of hexosyl lysine in hair and that there are only insignificant quantities of free hexoses present.

Although there were significant correlations between glycosylation of the proximal $4 \mathrm{~cm}$ of hair and the simultaneously measured glycosylated haemoglobin value, there was a considerable scatter in the results. This scatter may be due partly to variation in the rate of hair growth and the fact that the length of hair of $4 \mathrm{~cm}$ used in most of our experiments represents a period of roughly 16 weeks at an assumed average rate of hair growth of $0.37 \mathrm{~mm} /$ day. $^{7}$ In contrast, the closest correlations of glycosylated haemoglobin values have been with mean blood glucose concentrations in the preceding eight to 12 weeks. ${ }^{4}$ In addition, however, it seems likely that hair proteins are glycosylated in vivo with different dynamics from haemoglobin, an important factor when evaluating possible links between tissue glycosylation and diabetic microvascular complications.

The finding that hair glycosylation remains stable along the length of the hair from scalp to tip in normal subjects suggests that a sufficiently long hair sample may provide a long term record of degree of hyperglycaemia, though a prospective study will be necessary to establish this conclusively.

Further investigation into the chemical nature of glycosylation of hair is needed. In addition to epsilon amino groups of lysine residues in keratin, $\mathrm{N}$ terminal amino groups and perhaps even amino groups on melanin may be glycosylated. These would not all necessarily be accessible for hydrolysis in the thiobarbituric acid assay.

Although glycosylation of hair is likely predominantly to occur during secretion of the hair shaft in the follicle, glucose may become bound to the mature hair shaft from sweat, and any extraneous substances capable of producing furfurals in the assay might produce falsely high readings. This latter possibility is unlikely, as prolonged washing of hair samples did not affect the result.

Finally, if more work confirms these findings the tests may be of use forensically, because of the stability of fructosamine in the hair, and also in population studies, where large numbers of samples might be taken quickly as a non-invasive procedure and stored easily.

We thank the patients and control subjects for their cooperation, Miss Julia Ford and Mr Nick Bowyer for their help with the figure, and Mrs Zina Fear for preparing the manuscript.

\section{References}

1 Trivelli LA, Ranney HM, Hong Tiens L. Hemoglobin components in patients with diabetes mellitus. $N$ Engl f Med 1971 ;284:353-7.

${ }^{2}$ Koenig RJ, Peterson CH, Jones RL, Saudele C, Lehrman M, Cerami A. Correlation of glucose regulation and hemoglobin $A_{1 c}$ in diabetes mellitus. N Engl f Med 1976;295:417-20.

${ }^{3}$ Fluckiger R, Berger $\mathrm{W}$, Winterhalter $\mathrm{KH}$. Haemoglobin $\mathrm{A}_{1 \mathrm{c}}$, a reliable index of diabetic control. Diabetologia 1978;13:393.

${ }^{4}$ Bunn HF, Gabbay KH, Gallop PM. The glycosylation of $\mathrm{Hb}$; relevance to diabetes mellitus. Science 1978;200:21-7.

${ }^{5}$ Hall DA. Gerontology: collagen disease. Clin Endocrinol Metab 1981; $10: 23-55$.

${ }^{6}$ Barman JM, Astore J, Pecoraro V. The normal trichogram of the adult. f Invest Dermatol $1965 ; 44: 233-49$.

7 Munro DD. Hair growth measurement using intradermal sulphur 35 L-cystine. Arch Dermatol 1966;93:119-34.

${ }^{8}$ Menard L, Dempsey ME, Blankstein LA, Aleyassine H, Wacks M, Soeldner JS. Quantitative determination of glycosylated hemoglobin $A_{1}$ by agar gel electrophoresis. Clin Chem 1980;26:1598-602.

9 Parker KM, England JD, Da Costa J, Hess RL, Goldstein DE. Improved colorimetric assay for glycosylated hemoglobin. Clin Chem $1981 ; 27$ : 669-72.

${ }^{10}$ Bailey AJ. The non-enzymatic glycosylation of proteins. Horm Metab Res 1981;suppl 11:90-4.

${ }^{11}$ Clamp JR, Bhatti T, Chambers RE. The determination of carbohydrate in biological materials by gas liquid chromatography. Methods Biochem Anal 1971;19:229-344.

(Accepted 10 fanuary 1984)

\title{
Impairment of physical performance after treatment with beta blockers and alpha blockers
}

\author{
CALLE BENGTSSON
}

\begin{abstract}
An investigation was made into the effect of various types of beta blockers, an alpha blocker, a combined alpha and beta blocker, and a diuretic on physical performance in a normotensive man. Beta blockers, the alpha blocker, and the combined alpha and beta blocker significantly $(p<0.001)$ reduced physical performance.
\end{abstract}

Further studies are needed to confirm these findings in a larger series of subjects.

\footnotetext{
Medical Department II, Sahlgrenska Hospital, Gothenburg University, S-413 45 Gothenburg, Sweden

CALLE BENGTSSON, MD, associate professor of internal medicine
}

\section{Introduction}

Beta blockers have been in clinical use for more than 10 years and are often taken by young and physically active patients. As reduced cardiac output and heart rate are among the most important effects of these drugs ${ }^{1}$ a reduction in physical performance might be expected and has been observed. ${ }^{2}{ }^{3}$ This problem has been discussed previously, ${ }^{4}$ but few systematic studies of it have been made.

\section{Subject and method}

I investigated the effects of various types of beta blockers, an alpha blocker, and a combined alpha and beta blocker on my maximal physical performance. I was normotensive, had been a short-distance runner when younger, and was aged 40 when I performed the first trial in 1974. I had taken regular physical exercise in my spare time since adolescence. 
The effects of alpha and beta blockers and a diuretic were compared with those of a placebo. All the trials were carried out in a double blind crossover manner with active and placebo tablets of identical shape and taste. Three hours after taking each drug I ran $5000 \mathrm{~m}$ as fast as possible. I used the same cross country track each time and measured the time taken to complete the course (mean time with placebo in the first study $22 \mathrm{~min} 27 \mathrm{~s}$ ). My heart rate was recorded four minutes after I had stopped running. The significance of differences was determined with Student's $t$ test.

\section{Results}

The figure shows the results of a study in 1974 comparing the effects of alprenolol and placebo. The running time increased by about $50 \mathrm{~s}(\mathrm{p}<0.001)$ and the mean heart rate four minutes after the

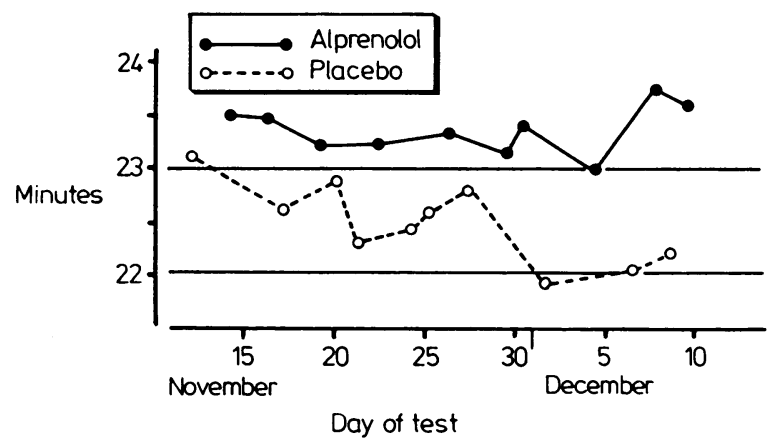

Time needed for running $5000 \mathrm{~m}$ after alprenolol and placebo and heart rate four minutes after finishing running. activity. There was no significant difference in effect between metoprolol, which is lipophilic, and atenolol, which is hydrophilic.

Maximal physical performance was significantly reduced by the alpha blocker prazosin $(p<0.001)$ and the combined alpha and beta blocker labetalol $(p<0.001)$. No significant difference in effect was observed between a diuretic (hydrochlorothiazide $25 \mathrm{mg}$ ) and placebo.

Heart rate after exercise was reduced after administration of all types of beta blockers and labetalol $(p<0.001)$ compared with placebo but not after administration of prazosin or hydrochlorothiazide.

Reproducibility of results was high with a small standard deviation within every exercise period for the different drugs used and placebo (6-76 $\mathrm{s}$ for time taken, $2-7$ beats/min for heart rate).

\section{Discussion}

It is important to obtain information about the degree of physical impairment caused by beta blockers and other antihypertensive drugs as the use of these drugs is increasing, especially among young and physically active patients. In addition, people are increasingly taking more physical exercise as a consequence of the recent craze for jogging.

The findings presented here were obtained from studies carried out in a uniform and scientific manner but with only one subject participating. Subjects with initially different physical capacities seem, however, to react to beta blockers in different ways. ${ }^{5}$ It cannot therefore be assumed that the same results would necessarily be obtained from other subjects. My findings must be confirmed by other studies, although it will be difficult to carry out such a systematic study in a large series of participants.

Mean increase in time taken to run $5000 \mathrm{~m}$ and mean difference in heart rate four minutes after finishing running after treatment with different types of alpha and beta blockers and a diuretic compared with placebo

\begin{tabular}{|c|c|c|c|c|c|c|c|}
\hline Year of test & Drug & $\begin{array}{l}\text { Dose } \\
\text { (mg) }\end{array}$ & No of runs & $\begin{array}{c}\text { Mean increase in } \\
\text { running time }\end{array}$ & $N$ & $\begin{array}{l}\text { Mean difference } \\
\text { in heart rate } \\
\text { (beats } / \mathrm{min} \text { ) }\end{array}$ & $\mathbf{p}$ \\
\hline 1974 & Alprenolol (Durules) & 200 & $\begin{array}{l}\text { Beta block } \\
10\end{array}$ & $50 \mathrm{~s}$ & $<0.001$ & -7 & $<0.001$ \\
\hline $\begin{array}{l}1975 \\
1975\end{array}$ & $\begin{array}{l}\text { Alprenolol } \\
\text { Alprenolol }\end{array}$ & $\begin{array}{l}100 \\
200\end{array}$ & $\begin{array}{l}\text { Effect of } d \\
5 \\
5\end{array}$ & $\left.\begin{array}{r}49 \mathrm{~s} \\
1 \mathrm{~min} 51 \mathrm{~s}\end{array}\right\}$ & $<0.01$ & $\begin{array}{l}-11 \\
-13\end{array}$ & NS \\
\hline $\begin{array}{l}1975 \\
1975\end{array}$ & $\begin{array}{l}\text { Metoprolol } \\
\text { Metoprolol }\end{array}$ & $\begin{array}{l}100 \\
200\end{array}$ & $\begin{array}{l}5 \\
5\end{array}$ & 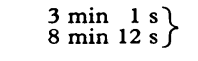 & $<0.001$ & $\begin{array}{l}-18 \\
-21\end{array}$ & NS \\
\hline \multicolumn{8}{|c|}{$\left.\begin{array}{c}\text { Selective v non-selective beta blocker } \\
30 \\
50\end{array} \begin{array}{ll}3 & \min 1 \mathrm{~s} \\
5 & 2 \min 32 \mathrm{~s}\end{array}\right\}$} \\
\hline $\begin{array}{l}1975 \\
1975\end{array}$ & $\begin{array}{l}\text { Propranolol } \\
\text { Alprenolol }\end{array}$ & $\begin{array}{l}E f f \\
80 \\
200\end{array}$ & $\begin{array}{l}\text { different deg } \\
5 \\
5\end{array}$ & $\left.\begin{array}{l}\text { of intrinsic activity } \\
2 \min 32 \mathrm{~s} \\
1 \mathrm{~min} 51 \mathrm{~s}\end{array}\right\}$ & $<0.001$ & $\begin{array}{r}-19 \\
-6\end{array}$ & $<0.001$ \\
\hline $\begin{array}{l}1980 \\
1980\end{array}$ & $\begin{array}{l}\text { Alprenolol (Durules) } \\
\text { Pindolol }\end{array}$ & $\begin{array}{r}200 \\
10\end{array}$ & $\begin{array}{l}5 \\
5\end{array}$ & $6 \min 37 s\}$ & $<0.001$ & $\begin{array}{r}-2 \\
-19\end{array}$ & $<0.001$ \\
\hline $\begin{array}{l}1979 \\
1979\end{array}$ & $\begin{array}{l}\text { Metoprolol } \\
\text { Atenolol }\end{array}$ & $\begin{array}{l}100 \\
100\end{array}$ & $\begin{array}{c}\text { ophilic } v \text { hydr } \\
4 \\
4\end{array}$ & $\begin{array}{l}\text { ailic beta blocker } \\
\left.\begin{array}{r}3 \min 25 \mathrm{~s} \\
4 \min 54 \mathrm{~s}\end{array}\right\}\end{array}$ & NS & $\begin{array}{l}-18 \\
-18\end{array}$ & NS \\
\hline \multicolumn{8}{|c|}{ 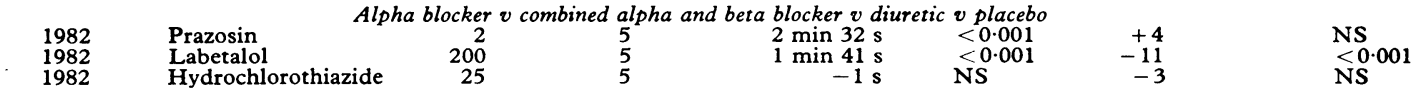 } \\
\hline
\end{tabular}

end of running was 7 beats/min lower with alprenolol $(\mathrm{p}<0.001)$ compared with placebo.

The table shows the results for all drugs tested. These indicate that beta blockers significantly reduce maximal physical performance and that this reduction is dose dependent in the cases of alprenolol $(\mathrm{p}<0.01)$ and metoprolol $(\mathrm{p}<0.001)$.

No significant difference in effect on maximal physical performance was shown when selective and non-selective beta blockers(metoprolol and propranolol) were compared in equally potent beta blocking doses. Neither of these drugs has intrinsic activity. The results concerning the effect of intrinsic activity were contradictory. Alprenolol, which has some intrinsic activity, only moderately impaired maximal physical performance compared with placebo, but there was significant impairment with pindolol $(p<0.001)$, which has high intrinsic

\section{References}

${ }^{1}$ Asström H. Haemodynamic effects of beta-adrenergic blockade. Br Heart $\mathcal{f}$ 1968;30:44-9.

${ }^{2}$ Epstein SE, Robinson BF, Kahler RL, Braunwald E. Effects of betaadrenergic blockade on the cardiac response to maximal and submaximal exercise in man. $\mathcal{F}$ Clin Invest 1965;44:1745-53.

${ }^{3}$ Ekblom B, Goldbarg AN, Kilbom $\AA$, Åstrand P-O. Effects of atropine and propranolol on the oxygen transport system during exercise in man. Scand 7 Clin Lab Invest 1972;30:35-42.

4 Breckenridge A. Jogger's blockade. Br Med $\mathcal{F}$ 1982;284:532-3.

${ }^{5}$ Furberg C. Adrenergic beta-blockade and physical working capacity. Acta Med Scand 1967;182:119-27.

(Accepted 15 December 1983) 